\title{
CONSCIENCE OR COERCION? CLERICAL INFLUENCE AT THE GENERAL ELECTION OF 1868 IN WALES
}

For many people in mid-nineteenth-century Britain, religious principle was the chief determinant of voting behaviour, and politics was perceived to be "an activity of significance mainly because religious issues were so prominent". " The importance of religious questions at election time naturally brought politics within the purview of the church and the chapel. In general terms, the Anglican clergy, though overwhelmingly Conservative in their voting behaviour, tended to shrink from contact with the electoral process itself. ${ }^{2}$ The dissenting ministers, however, embraced it, and enrolled themselves as unflagging champions of the Liberal cause. As John Vincent once observed: "No other occupation was so partisan, so militant, so unfloating, as the Dissenting ministers. They were a sort of Communist hardcore of the Popular Front". ${ }^{3}$ The Catholic clergy, meanwhile, especially in Ireland, took a similarly prominent role in the organization of politics, having a crucial voice in everything from the choice of the candidate to the refreshment of the voters on polling-day. ${ }^{4}$

Given the extent of their involvement, it is surprising that so little historical attention has been paid to the role of preachers and

' J. Parry, Democracy and Religion: Gladstone and the Liberal Party, 1867-1875 (Cambridge, 1986), p. 5. For the early nineteenth century, see J. A. Phillips, The Great Reform Bill in the Boroughs (Oxford, 1992), p. 294; J. Bradley, "Religion and Reform at the Polls", $f l$ Brit. Studies, xxiii (1984), pp. 55-78; J. Bradley, "Nonconformity and the Electorate in Eighteenth-Century England", Parliamentary History, vi (1987), pp. 236-61.

${ }^{2}$ E. R. Norman, Church and Society in England, 1770-1970 (Oxford, 1976), p. 167. Exceptions to this general rule can be found. The archdeacon of Chester, for example, preached a sermon on the eve of the poll, warning his audience that the pollbooks would be opened on Judgement Day: Report from the Select Committee on Parliamentary and Municipal Elections, Parliamentary Papers (hereafter P.P.), 1868-9 (352), viii, q. 6456 .

${ }^{3}$ J. R. Vincent, Pollbooks: How Victorians Voted (Cambridge, 1968), p. 18.

${ }^{4}$ J. H. Whyte, The Independent Irish Party, 1850-1859 (Oxford, 1958), pp. 63-81; J. H. Whyte, "The Influence of the Catholic Clergy on Elections in NineteenthCentury Ireland”, Eng. Hist. Rev., lxxv (1960), pp. 239-59. Catholic clergy were also active in England: P. F. Clarke, Lancashire and the New Liberalism (Cambridge, 1971), pp. 255-6. 
priests in politics. ${ }^{5}$ It is the more so since there were loud complaints throughout the middle years of the century, particularly from the countries of the Celtic fringe, that both the dissenting ministers and the Catholic clergy were interfering improperly in elections. The catalogue of abuses alleged against the priests in Ireland, which would have been equally familiar to politicians in the more remote and less modernized areas of France and Germany, as well as in Wales, may serve to indicate what contemporaries meant when they spoke of "clerical influence". 6 In their clerical capacity, Irish priests apparently delivered addresses from the altar in support of particular candidates and condemned members of the congregation who refused to follow their political lead, sometimes with quasi-religious comminations. ${ }^{7}$ They were accused

${ }^{5}$ For the influence of the Pease-Backhouse Quaker connection in County Durham, see T. J. Nossiter, Influence, Opinion, and Political Idioms in Reformed England: Case Studies from the North-East, 1832-74 (Brighton, 1975), pp:61-4. Methodists rarely expressed any collective opinion on political matters: R. Moore, Pit-Men, Preachers and Politics: The Effects of Methodism in a Durham Mining Community (Cambridge, 1974 ), p. 159. British anti-clericalism is held to have peaked in the 1830 s, and this may be the cause of historians' silence on "clerical influence": E. J. Evans, "Some Reasons for the Growth of English Rural Anti-Clericalism, c.1750 - c.1830", Past and Present, no. 66 (Feb. 1975), pp. 84-109; for anti-clerical feeling among mid-Victorian radicals, see E. F. Biagini, Liberty, Retrenchment and Reform: Popular Liberalism in the Age of Gladstone, 1860-1880 (Cambridge, 1992), pp. 192-253. Alternatively, it might be that historians have perceived it to be "a peculiarly Irish practice": C. O'Leary, The Elimination of Corrupt Practices in British Elections, 1868-1911 (Oxford, 1962), p. 202.

${ }^{6}$ This paragraph is based upon the following: J. O'Shea, Priest, Politics and Society in Post-Famine Ireland: A Study of Co. Tipperary, 1850-1891 (Dublin, 1983), p. 44; A. Macintyre, The Great Liberator: Daniel O'Connell and the Irish Party, 1830-47 (London, 1965), pp. 111-17; K. T. Hoppen, Elections, Politics and Society in Ireland (Oxford, 1984), pp. 246-7; Whyte, "Influence of the Catholic Clergy on Elections", pp. 244-8; D. Blackbourn, Class, Religion and Local Politics in Wilhelmine Germany: The Centre Party in Württemburg before 1914 (New Haven, 1980); M. L. Anderson, "The Kulturkampf and the Course of German History", Central European Hist., xix (1986), pp. 82-115; M. L. Anderson, "Voter, Junker, Landrat, Priest: The Old Authorities and the New Franchise in Imperial Germany", Amer. Hist. Rev., xcviii (1993), pp. 1448-74; P. M. Jones, Politics and Rural Society: The Southern Massif Central, c.1750-1880 (Cambridge, 1985); S. Berger, Peasants against Politics: Rural Organization in Brittany, 1911-1967 (Cambridge, Mass., 1972), p. 43; W. D. Irvine, The Boulanger Affair Reconsidered: Royalism, Boulangism and the Origins of the Radical Right in France (Oxford, 1989), p. 55; and more generally, G. Cubitt, The Fesuit Myth: Conspiracy Theory and Politics in Nineteenth-Century France (Oxford, 1993).

${ }^{7}$ Whyte, "Influence of the Catholic Clergy on Elections", pp. 245-6; Hoppen, Elections, Politics and Society in Ireland, pp. 211-24. Priests were held to possess magical powers, which allowed them to indulge in such cursing: Hoppen, Elections, Politics and Society in Ireland, pp. 246-7; for an example, see O'Shea, Priest, Politics and Society in Post-Famine Ireland, p. 46. See also Jones, Politics and Rural Society, pp. 233-41, 284-95. 
of denying the sacraments to those who had refused to vote as directed, and of threatening them with eternal damnation as the necessary consequence of their action. ${ }^{8}$ It was said that they openly characterized their opponents as the agents of the Devil, whilst describing votes cast for their side, conversely, as blessed by the pope. ${ }^{9}$ Examples were cited of their leading voters straight from the altar-rails to the polling-booths and supervising the votes cast, and of their exploiting the secrecy of the confessional to discover the nature of votes given under protection of the ballot. ${ }^{10}$ In short, contemporaries objected to political involvement "by the priest as a priest"," deeming it an attempt to exploit the ignorance or superstition of voters in country areas.

These complaints were deemed sufficiently serious for the Corrupt Practices Act of 1883 to declare illegal the threatening of "any temporal or spiritual injury, damage, harm, or loss upon or against any person in order to induce or compel such person to vote or refrain from voting". ${ }^{12}$ Yet historians have tended to downplay the allegedly coercive aspects of clerical involvement in Irish elections, a caution dictated in part by the nature of the evidence. In the first place, it is clear that whilst the clergy were undoubtedly involved in elections, the nature of their interference was often wilfully exaggerated by political opponents. ${ }^{13}$ Secondly, it is unclear how effective threatening behaviour by priests was or could have been. Although parliamentary candidates certainly considered the priests an important force, and actively courted their support, ${ }^{14}$ the backing of the priests by no means ensured

${ }^{8}$ Berger, Peasants against Politics, p. 46; Blackbourn, Class, Religion and Local Politics in Wilhelmine Germany, pp. 108-10.

${ }^{9}$ O'Leary, Elimination of Corrupt Practices in British Elections, p. 57; Anderson, "Kulturkampf and the Course of German History", p. 91.

${ }^{10}$ Whyte, Independent Irish Party, pp. 63-81; O'Shea, Priest, Politics and Society in Post-Famine Ireland, p. 51; Anderson, "Voter, Junker, Landrat, Priest", pp. 1452-3.

"O'Shea, Priest, Politics and Society in Post-Famine Ireland, p. 44.

${ }^{12}$ Cited in Hoppen, Elections, Politics and Society in Ireland, p. 248 n. 2 (emphasis supplied). This link is not made by O'Leary, Elimination of Corrupt Practices in British Elections, pp. 159-78. Such laws had been in force in Germany since 1871: Anderson, "Kulturkampf and the Course of German History", pp. 107-8, see also p. 105 n. 53.

${ }^{13}$ Anderson, "Kulturkampf and the Course of German History", pp. 93-4; Blackbourn, Class, Religion and Local Politics in Wilhelmine Germany, p. 109. J. E. C. Bodley complained that the evidence used in France of "clerical influence" was often accepted on the "vaguest hearsay", and involved actions of so mild a nature that were comparable criteria to be used in England there would scarcely be a member left in the House of Commons: J. E. C. Bodley, France, 2 vols. (London, 1898), ii, pp. 123-4.

${ }^{14}$ Hoppen, Elections, Society and Politics in Ireland, pp. 248-51. 
success. ${ }^{15}$ Furthermore, even when a result was obtained it is not clear that priestly threats were the crucial factor. Some historians have suggested that it would have been impossible for a priest to coerce his congregation anyway, since he was effectively their employee and dependent upon them for his living. If he opposed their will, he might find collections diminishing, or suffer more immediately violent retaliation. ${ }^{16}$ As a consequence of these reservations, it has been suggested that the chief means by which priests influenced politics was their ability to organize the electorate in remote areas. ${ }^{17}$

Great though their organizational efficiency was, however, to accord the clergy no other influence among communities with which they enjoyed an intimate and broad-ranging everyday relationship seems unrealistic. ${ }^{18}$ As K. T. Hoppen has remarked, "clerical influence" must mean something more than "the simple alteration of votes" at election time; it must be conceived in wider terms and allow for the "gradual moulding of opinion" which a cleric might effect within the community. ${ }^{19}$ In this article, the wider perspective suggested by Hoppen will be used as the basis for an examination of the allegations of "clerical influence" levelled against the nonconformist ministers in Wales. ${ }^{20}$ The

${ }^{15}$ Whyte, "Influence of the Catholic Clergy on Elections", pp. 246-8; Hoppen, Elections, Politics and Society in Ireland, pp. 248-51; O'Shea, Priest, Politics and Society in Post-Famine Ireland, pp. 48-9; cf. I. Farr, "Peasant Protest in the Empire: The Bavarian Example", in R. G. Moeller (ed.), Peasants and Lords in Modern Germany: Recent Studies in Agricultural History (Boston, 1986), p. 119.

${ }^{16}$ Whyte, "Influence of the Catholic Clergy on Elections", p. 248; K. B. Nowlan, "The Catholic Clergy and Irish Politics in the Eighteen Thirties and Forties", Historical Studies, ix (1974), pp. 119-36; J. A. Murphy, "The Support of the Catholic Clergy in Ireland, 1750-1850", ibid., v (1965), pp. 103-21; S. White, Social Origins of the Irish Land War (Princeton, 1979), p. 195; E. R. Norman, The Catholic Church and Ireland in the Age of Rebellion, 1859-1873 (London, 1965), pp. 108-9.

${ }^{17}$ Whyte, Independent Irish Party, p. 79; Whyte, "Influence of the Catholic Clergy on Elections", pp. 249-51.

${ }^{18}$ White, Social Origins of the Irish Land War, p. 79; G. Dallas, The Imperfect Peasant Economy: The Loire Country, 1800-1914 (Cambridge, 1982), pp. 84-5.

${ }^{19}$ Hoppen, Elections, Politics and Society in Ireland, p. 255.

${ }^{20}$ The role of nonconformist ministers in Welsh politics has been curiously neglected, though their involvement has been noted in broader discussions of larger issues, i.e., language: I. G. Jones, "Language and Community in Nineteenth-Century Wales", in his Mid-Victorian Wales (Cardiff, 1992), pp. 54-102; politics: I. G. Jones, Explorations and Explanations: Essays in the Social History of Wales (Llandyssul, 1981); R. Wallace, Organise! Organise! Organise! A Study of Reform Agitations in Wales, 1840-1886 (Cardiff, 1992); D. Howell, Land and People in Nineteenth-Century Wales (London, 1977), pp. 64-5; the temperance movement: W. R. Lambert, Drink and Sobriety in Victorian Wales (Cardiff, 1981); and the peace movement: Goronwy J. Jones, Wales and the Quest for Peace (Cardiff, 1969). The chapels are discussed in 
ministers were accused of precisely the same range of spiritual intimidation familiar in Irish elections. As in Ireland, such charges were no doubt grossly exaggerated (they are certainly impossible to prove). Nevertheless, it will be argued here that, however dubious on their own, they suggest an alternative interpretation of "clerical influence" which, while rejecting the full-blown "spiritual terrorism" claimed by contemporary Conservative opponents, yet accords the preachers something more than a merely organizational role in politics.

It will be suggested that the key to understanding "clerical influence" lies in placing the "supernatural" threats in the context of the preacher's everyday relationship with his congregation. The work of the nonconformist minister was to imbue his congregation with a moral instinct, an ability to differentiate between good and evil. The congregation so taught vested in its hierarchy the power to discipline, on their behalf, those such as drunkards or adulterers who transgressed the boundaries of morality as understood by the community. At election time, the role of the preacher was the same: he pointed out to his congregation the moral aspect of politics, interpreting those issues within the framework of the shared moral precepts upon which they based their everyday lives. In essence, as will be seen, he reduced politics to a simple choice between "good" and "evil", and implored his congregation to deliver their votes in line with "conscience", that is, in accordance with the morality learned in chapel to which the community subscribed. Those who chose not to heed this advice might expect the sanctions normally imposed on members who flouted chapel morality: warnings of the damnatory consequences of their independent choice; the humiliation of being "named" in front of the congregation for their sin; suspension from the chapel until the sin was properly repented of; and, in extreme cases, excommunication. What is important about all these forms of punishment, however, is their collective element. The minister could not have effected any of them on his own; all required the acquiescence of the wider community,

(n. 20 cont.)

E. T. Davies, Religion and Society in the Nineteenth Century (Llandybie, 1981), pp. 35-46, 61-77. Although the Calvinistic and Wesleyan Methodists should properly be termed "nonconformists" and the Baptists and Independents (Congregationalists) "dissenters", the terms are used interchangeably throughout this paper, as they were by contemporaries. By 1868 , all nonconformist and dissenting denominations in Wales shared one view of politics. 
enfranchised and unenfranchised alike, represented by the chapel congregation. "Conscience", therefore, far from belonging solely to the individual, was ultimately the preserve of the community, ${ }^{21}$ and "clerical influence" is perhaps best understood as the minister leading the enforcement of a collectively held morality against those within the community who would flout it. ${ }^{22}$

It is arguable that there was in this process a recognizable echo of the older rituals by which community morality was enforced on miscreants such as adulterers and wife-beaters, not only in the form taken by the punishments but also in the psychology underpinning them. ${ }^{23}$ That link will be explored further below, but the focus of this article will be the activities of the nonconformist ministers at the general election of 1868. After a brief introduction to the place of the chapel in Victorian Wales, the political influence of the preachers at that election will be examined and the charges made against them by the Conservatives explored. Attention will then turn to the relationship between older forms of community morality and that enforced in the chapels, before, finally, the extent to which a similar social dynamic might underpin "clerical influence" in Ireland will be touched on.

\section{I}

Nineteenth-century Wales was a "nation of nonconformists". On Census Sunday 1851, fully eighty per cent of those who attended a place of worship in the principality did so under the auspices of the chapels. ${ }^{24}$ Even those not formally connected with any of the four large denominations which dominated the principality's religious life were not untouched by the moral aura emanating

${ }^{21}$ R. J. Helmstadter, "The Nonconformist Conscience", in P. Marsh (ed.), The Conscience of the Victorian State (Hassocks, 1979), p. 157.

${ }^{22}$ Such an approach complements the emphasis placed by both David Blackbourn and P. M. Jones on the extent to which political identities were shaped by a variety of pressures within the community: Blackbourn, Class, Religion and Local Politics in Wilhelmine Germany, pp. 108-10; P. M. Jones, "An Improbable Democracy: Nineteenth-Century Elections in the Massif Central", Eng. Hist. Rev., xcvii (1982), pp. 530-57.

${ }^{23}$ E. P. Thompson, "Rough Music", in his Customs in Common (London, 1991), pp. 467-533. Irish elections demonstrated something similar: Whyte, Independent Irish Party, p. 69; K. T. Hoppen, "Grammars of Electoral Violence in Nineteenth-Century England and Ireland", Eng. Hist. Rev., cix (1994), pp. 597-620.

${ }^{24}$ The Religious Census of 1851: A Calendar of the Returns Relating to Wales, ed. I. G. Jones and D. Williams, 2 vols. (Cardiff, 1976). 
from the chapels. The chapels "dictated a quality of life to a whole society", writes Kenneth Morgan, regulating its moral timbre with puritanical strictness, whilst simultaneously providing the starting-point for a rich popular culture whose creative focus was the eisteddfod: "with all its limitations", he continues, "nonconformity was responsible for almost every significant and worthwhile aspect of social and cultural activity in late nineteenthcentury Wales". ${ }^{25}$ It was not only a social and cultural influence. Nonconformity also formed the basis of the distinctively "Welsh" political identity which emerged in the years after 1868 , finding expression first in support of Gladstonian Liberalism, and later in the nationalist programme of Cymru Fydd ("Young Wales"). ${ }^{26}$ A brief survey of chapel culture, and of the position of the nonconformist minister within it, therefore provides an important background to what follows.

The institutional life of the chapel was an intense experience. Membership entailed commitment: those who had been admitted into the chapel community were expected not only to attend on Sundays (almost always at least twice) but also to take part in the midweek siety (society) meetings. The Sunday services were formally organized around the sermon, the great evangelizing weapon of Welsh nonconformity. ${ }^{27}$ The siety was more intimate, as the Revd Thomas Rees, an Independent minister, described. At these meetings, said Rees, the minister might deliver a short address and then invite the deacons and other elders to discuss their own religious experiences for the edification of their less experienced fellows. Alternatively, he might use the time to "give appropriate exhortations to different classes, such as heads of families, the aged, the young, masters, servants, the poor, or the afflicted". Occasionally, he continued, "the members are addressed personally, in the presence of the whole Society, and encouraged, warned or directed according to their different characters". Such services were apparently considered by the dissenting bodies in Wales as "the most important and useful

\footnotetext{
${ }^{25}$ K. O. Morgan, Rebirth of a Nation: Wales, 1880-1980 (Oxford, 1981), pp. 13-18; Davies, Religion and Society in the Nineteenth Century, p. 64.

${ }^{26}$ The standard account remains Morgan, Wales in British Politics.

${ }^{27}$ R. Griffiths, "Welsh Chapel Music: The Making of a Tradition", $\mathfrak{f l}$ Welsh Eccles. Hist., vi (1989), pp. 35-43; Davies, Religion and Society in the Nineteenth Century, pp. 35-6; Revd W. Rees, Memoirs of the late Rev. W. Williams, of Wern, trans. J. R. Jones (London, 1846), pp. 162-84.
} 
religious services" they had: ${ }^{28}$ Rees's comments certainly indicate the extent to which the "confessional" nature of the siety might allow the preacher to lead the chapel community's policing of its members' morals. ${ }^{29}$

The brand of religion preached in the chapels fostered the intense and emotional character of Welsh dissent. ${ }^{30}$ In theological matters, Welsh nonconformity was singularly unprogressive. Although periodicals such as $Y$ Traethodydd, founded in 1845, kept their readers in touch with new currents of thought in English and German theology, ${ }^{31}$ Welsh nonconformity was dominated by an extreme form of puritanism for much of the century. Its theological touchstone was Thomas Charles's bible dictionary, $Y$ Geiriadur, which took for its authorities the Puritan divines. The tenor of Welsh religion was correspondingly Calvinistic, centred around a belief in original sin, the inherent depravity of mankind, free justification through the acknowledgement of Christ's sacrifice, effectual grace in regeneration, the everlasting happiness of the righteous and the eternal punishment of the wicked. ${ }^{32}$ Only at the end of the century was this cocktail of hellfire and atonement replaced by a stress on God's redeeming mercy as shown in the incarnation. ${ }^{33}$ As W. R. Lambert has commented, the nonconformists felt themselves to be the righteous besieged in a world of sin, a view that was clearly reflected in the titles of their most famous hymns: "Alone on the Raft", "Hold the Fort" and "The Heavy Cross". ${ }^{34}$ Two consequences flowed from the nature of chapel theology. First, Welsh nonconformity was highly Manichaean and authoritarian: it saw the world in black and

${ }^{28}$ Revd T. Rees, The Congregational Churches of Wales (London, 1858), pp. 76-7; cf. Moore, Pit-Men, Preachers and Politics, pp. 103-18.

29 "A Montgomeryshire Man", The Principality; or, The Wants of Wales Considered (London, 1851), p. 18.

${ }^{30}$ Reports of the Commissioners of Inquiry into the State of Education in Wales, 3 pts, P.P., 1847 (870-2), xxvii, iii, p. 6.

${ }^{31} \mathrm{~K}$. Robbins, Nineteenth-Century Britain: Integration and Diversity (Oxford, 1988), p. 86.

${ }^{32}$ Revd T. Rees, "The Working Classes of Wales and Religious Institutions", in his Miscellaneous Papers on Subjects relating to Wales (London, 1867), p. 24.

${ }^{33}$ Davies, Religion and Society in the Nineteenth Century, pp. 65-8; M. R. Watts, "' 'The Hateful Mystery': Nonconformists and Hell", fl United Reformed Church Hist. Soc., ii (1981), pp. 248-58; B. Hilton, The Age of Atonement: The Influence of Evangelicalism on Social and Economic Thought, 1785-1865 (Oxford, 1988), pp. 255-339.

${ }^{34}$ Lambert, Drink and Sobriety in Victorian Wales, p. 116; A. Howkins, Poor Labouring Men: Rural Radicalism in Norfolk, 1872-1923 (London, 1985), pp. 39-41. 
white, as divided between right and wrong. Secondly, the embattled nature of the group psychology encouraged the strong mutual support and protection against sinful behaviour which was so important a part of the siety meetings.

In addition to the institutional commitment required of believers and the uncompromising nature of its theology, chapel life in Wales was also characterized by its social context. In many areas the congregation was essentially coterminous with the community itself: $:^{35}$ even where this was not the case (and quite remote parishes could often boast several chapels), ${ }^{36}$ those who prayed and worshipped together formed a very close-knit social group within the larger community. The divisions of status found in the world beyond the chapel walls were reflected in the hierarchy of the chapel itself, and a majority of the elders and deacons were invariably drawn from the higher echelons of the local community, the farmers. ${ }^{37}$ Rural society in Wales, though lacking the class demarcations of the English countryside, nevertheless observed a distinct status line between farmers and labourers, ${ }^{38}$ and since farmers traditionally enjoyed a more prolonged exposure to education in childhood and a greater amount of leisure time in adulthood, ${ }^{39}$ leadership of both the secular and religious communities, perhaps inevitably, devolved on to their shoulders. As Ieuan Gwynedd Jones has written, they were effectively the middle class of the countryside, "in the highest sense, the legislators of their times": ${ }^{40}$ it was from this group that most deacons

${ }^{35} \mathrm{~K}$. Verdery, "Ethnicity and Local Systems", in C. A. Smith (ed.), Regional Analysis, 2 vols. (New York, 1976), ii, p. 213. For the extent to which such communities formed the basis for organization in the Irish countryside, see S. Clark, "The Political Mobilisation of Irish Farmers", in A. O'Day (ed.), Reactions to Irish Nationalism (London, 1987), pp. 61-78.

${ }^{36}$ Religious Census of 1851 , ed. Jones and Williams.

${ }^{37}$ M. Fitton and G. Day, "Religion and Social Status in Rural Wales", Sociol. Rev., new ser., xxiii (1975), pp. 867-91. This reflected the fact that the chapel edifice was often in their names, a role for which poor people would not have been acceptable: Report from the Select Committee on Parliamentary and Municipal Elections, q. 5177. For an English example, see A. Howkins, Reshaping Rural England: A Social History, 1850-1925 (London, 1991), p. 181.

${ }^{38}$ Howell, Land and People in Nineteenth-Century Wales, pp. 63, 93-4; D. Jenkins, The Agricultural Community of South-West Wales at the Turn of the Twentieth Century (Cardiff, 1971), pp. 101, 130.

${ }^{39}$ Reports of the Commissioners of Inquiry into the State of Education in Wales, i, pp. 8, 12; D. J. V. Jones, Rebecca's Children (Oxford, 1990), p. 78.

${ }^{40} \mathrm{I}$. G. Jones, "The Dynamies of Welsh Politics", in his Explorations and Explanations, p. 293; Wallace, Organise! Organise! Organise!, pp. 88-90, 115, 135-6. 
came. ${ }^{41}$ In the towns, the majority of chapel officials would appear to have been drawn from the ranks of the shopocracy and craftsmen. ${ }^{42}$ No research has been conducted into the background of the men who became ministers, but it is likely that they too came chiefly from the higher part of rural society, from that part used to leading opinion in the community. ${ }^{43}$ This was certainly true of nonconformist ministers in England, the Catholic clergy in Ireland and those training for the Anglican ministry in Wales. ${ }^{44}$ For those who did rise from the lower reaches of society, meanwhile, their temporal reward was translation into the high-status group. The many preachers who were obliged to seek supplementary work to pad out inadequate stipends turned to farming or shopkeeping; few, one imagines, toiled as labourers. ${ }^{45}$

The temporal position of the nonconformist ministers in relation to their congregations did not rest solely on the advantages

41 This did not escape criticism from contemporaries: see the anonymous pamphlet Calvinistic Methodism in Wales: Its Present Position and Future Prospects (London, 1870), pp. 8-9.

${ }^{42}$ Of the 260 identifiable deacons and other church officers who signed their respective chapels' returns to the 1851 religious census, only 26 (10 per cent) were labourers, a figure which includes 10 miners; the rest were overwhelmingly drawn from the ranks of shopkeepers and tradesmen (169: 63 per cent): Religious Census of 1851 , ed. Jones and Williams. This confirms the picture provided by the following: Fitton and Day, "Religion and Social Status in Rural Wales"; Memoir and Sermons of the late Rev. David Lloyd fones, ed. Revd R. Hughes (Wrexham, 1912), pp. 38-9.

${ }^{43}$ H. T. Edwards, The Church of the Cymry: A Letter to the Right Hon. W. E. Gladstone (Aberdare, 1870), pp. 40-4.

${ }^{44}$ D. T. W. Price, $A$ History of Saint David's University College, Lampeter, 2 vols. (Cardiff, 1977-90), i, pp. 49, 126; K. D. Brown, $A$ Social History of the Nonconformist Ministry in England and Wales, 1800-1930 (Oxford, 1988), pp. 19-55; Norman, Catholic Church and Ireland in the Age of Rebellion, p. 14; Hoppen, Elections, Politics and Society in Ireland, pp. 174-5; D. Kerr, Peel, Priests and Politics: Sir Robert Peel's Administration and the Roman Catholic Church in Ireland, 1841-1846 (Oxford, 1982), pp. 238-48. This was also true of the Catholic clergy on the Continent: R. Gibson, "Why Republicans and Catholics Couldn't Stand Each Other in the Nineteenth Century", in F. Tallett and N. Atkin (eds.), Religion, Society and Politics in France since 1789 (London, 1991), p. 112.

${ }^{45}$ Many ministers received very low stipends; it was estimated that an Independent minister's stipend averaged less than $£ 60$, and that during the 1870 s the average Calvinistic Methodist minister received only between $£ 50$ and $£ 100$ : Rees, Congregational Churches of Wales, p. 80; R. B. Knox, Wales and " $Y$ Goleuad" (1869-1879) (Caernarfon, 1969), p. 66; Anon., Calvinistic Methodism in Wales, pp. 25-7. Similar figures have been given for Primitive Methodist ministers: J. Obelkevich, Religion and Rural Society: South Lyndsey, 1825-1875 (Oxford, 1976), p. 223. For the income of Anglican clergy in Wales at this time, see M. Cragoe, "The Tory and Anglican Gap in Welsh Historiographical Perceptions: The Case of Carmarthenshire, $c .1832-85$ " (Univ. of Oxford D.Phil. thesis, 1990), pp. 343-4. In Ireland, it was said that a "great many" priests also ran a small farm: Hoppen, Elections, Politics and Society in Ireland, pp. 178-9. 
derived from their inherited (or achieved) social status within the community. They were also set apart by their greater education. ${ }^{46}$ The many institutions established to train young preachers and their number increased sharply after 1832 - were important not only for the range of studies they offered, but also for their urban location. The Calvinistic Methodists had colleges in Bala (founded 1837) and Trefecca (1842); the Independents, in Brecon (1755), Bangor (1841) and Carmarthen (1862); and the Baptists, in Cardiff (1806) and Bangor (1862), a spread of dates which suggests an important connection between the greater availability of education and the increased political activity of the nonconformist ministers from the 1830s. The urban context of these colleges is all-important in explaining this link: it allowed young preachers to experience an intellectual milieu far removed from the paternalism of the countryside. ${ }^{47}$ Nonconformist ministers thus returned to rural areas possessing not only a wider education and experience of the world than their flocks, but also a very different, less deferential view of politics.

The net effect of these social and educational advantages was to give the nonconformist minister an authority and an influence which transcended his religious calling. At the local level, the minister was the focal point of moral influence in his community, and contemporaries were quick to acknowledge that the relationship between the community and their preacher was not confined to religious matters alone. As one witness told the Select Committee on Parliamentary and Municipal Elections in 1869, "a Welsh farmer looks to his dissenting minister as his chief adviser in all things". ${ }^{48}$ The ministers were similarly influential at the national level, where their relative breadth of experience and vision made them natural leaders of public opinion. It is not surprising, therefore, that nonconformist ministers controlled a large part of the Welsh-language press, either as editors or as

\footnotetext{
${ }^{46}$ Education was viewed suspiciously by some, as being likely to damage the recipient's ability to preach with "fire": Memoir and Sermons of the late Rev. David Lloyd fones, ed. Hughes, p. 29. This view was shared by Primitive Methodists in Norfolk: Howkins, Poor Labouring Men, p. 46. On Sunday school education in Wales, see I. G. Jones, "1848 and 1868: 'Brad y Llyfrau Gleision' [Treason of the Blue Books]", in his Mid-Victorian Wales, pp. 132-6.

${ }^{47}$ M. Cragoe, An Anglican Aristocracy: The Moral Economy of the Landed Estate in Carmarthenshire, c.1832-1895 (Oxford, forthcoming).

${ }^{48}$ Report from the Select Committee on Parliamentary and Municipal Elections, q. 5233.
} 
major shareholders, throughout the century. ${ }^{49}$ No fewer than twenty-three of the twenty-five periodicals circulating at the time of the Welsh Land Commission Report in 1896, and one-third of the weekly papers, were edited by nonconformist ministers. ${ }^{50}$ The latter, particularly, represented a very important forum for the discussion of political matters. Both nationally and locally, therefore, the dissenting clergy occupied a position of political leadership in Wales.

The nonconformist ministers had been increasingly active in politics from the 1830s, and at periods of particular excitement, such as the elections of 1835 and 1837 , had played a key role in some areas. $^{51}$ Their influence continued to be an important factor in both national and local politics throughout the century, but in 1868 it reached unprecedented levels. ${ }^{52}$ This was partly because the Second Reform Act, having increased the old electorate by some 250 per cent, effectively invalidated the old balance of power in many constituencies and encouraged challenges, with the consequence that there were many more contests in 1868 than at any time since $1832 .{ }^{53}$ Equally important, however, was

${ }^{49}$ A. Jones, Press, Politics and Society: A History of Journalism in Wales (Cardiff, 1993), pp. 118-24; G. A. Williams, When was Wales? (London, 1985), pp. 207-8.

${ }_{50}$ Bibliographical, Statistical and other Miscellaneous Memoranda, being Appendices to the Report of the Royal Commission on Land in Wales and Monmouthshire, P.P., 1896 (C. 8242), xxxiii, pp. 195-6, Table III; [J. Vincent], Letters from Wales (London, 1889), pp. 122-3. Conservatives and Anglicans recognized the importance of the Welsh-language press and attempted to start up their own papers in the native tongue, but these were largely unsuccessful: T. Lewis, The Welsh Church Press (Neath, 1879); Jones, Press, Politics and Society, pp. 123-4.

${ }^{51}$ R. L. Hugh, "The Theological Background of Nonconformist Social Influence in Wales, 1800-1850" (Univ. of London Ph.D. thesis, 1951), pp. 198-234; M. Cragoe, "Carmarthenshire County Politics, 1804-37", Carmarthenshire Antiquary, xxx (1994), pp. 70-7. Their activity was widespread in Merioneth between 1859 and 1868: I. G. Jones, "Merioneth Politics at Mid-Century", in his Explorations and Explanations, pp. 83-164. The Calvinistic Methodists, whose strength lay in north Wales, remained aloof from politics until the late 1840s: Morgan, Wales in British Politics, pp. 15-17.

${ }_{52}$ Cragoe, Anglican Aristocracy, ch. 8.

${ }^{53}$ In 1868, only 14 candidates from Wales were returned unopposed to parliament, whereas (with the exception of 1837 , when 17 were so returned) the number never dropped below 22 at elections held between 1832 and 1865: A. J. James and J. E. Thomas, Wales at Westminster: $A$ History of the Parliamentary Representation of Wales, 1800-1979 (Llandyssul, 1981), pp. 66-8, 196-7. See also Jones, "Merioneth Politics at Mid-Century"; R. Merfyn Jones, The North Wales Quarrymen, 1874-1922 (Cardiff, 1981). 
the prominence at the election of a religious issue: the election was effectively a referendum on whether the (Anglican) Church of Ireland should be disestablished. To nonconformists, the link between church and state was unscriptural and thus untenable. That the election should have been dominated by this issue was particularly opportune since, throughout the 1860 s, Wales had been the focus for Liberation Society agitation; not only had their pro-disestablishment ideas received wide dissemination at large public meetings, but they had also paid considerable attention to the electoral registers in key constituencies such as Cardiganshire. ${ }^{54}$ The Liberal party, and the most important interest group supporting it, the nonconformists, were thus well prepared for battle in 1868 .

In the event, the Conservatives suffered severe losses across Wales, and were beaten out of seats they had held for generations. ${ }^{55}$ Defeated candidates were not slow to identify the source of their confusion: it was, said one, due to the "unbridled play of interested bigotry and sectarian hate . . . upon the side of the Liberal candidates . . . exercised by the Nonconformist Ministers throughout the country". ${ }^{56}$ In Carnarvonshire, meanwhile, Colonel Pennant spoke of the "formidable combination" of preachers that had opposed him, and likened the current state of Wales to "the dark days in Spain and Ireland [when] the people were held in thraldom by the priests". ${ }^{57}$ In this section, the charges levelled against the ministers by Colonel Pennant and other Welsh Conservatives will be investigated. Attention will be paid first to the preachers' organizational role, before the focus shifts to the various ways in which they conflated political and religious roles during the campaign. Finally, some attempt will

54 I. G. Jones, "The Liberation Society in Welsh Politics", in his Explorations and Explanations, pp. 236-68; Wallace, Organise! Organise! Organise!, pp. 122-36, 184-211; National Library of Wales, Aberystwyth, Henry Richard MSS., 14021/D, fo. 126, Revd John Davies to Henry Richard, 14 July 1865.

${ }^{55}$ For a summary, see Morgan, Wales in British Politics, pp. 22-7. Particular contests are covered in: J. Morgan, "Denbighshire's annus mirabilis: The Borough and County Elections of 1868", Welsh Hist. Rev., vii (1974), pp. 63-87; Cragoe, "Tory and Anglican Gap in Welsh Historiographical Perceptions", pp. 240-71. For elections in Merioneth, Cardiganshire and Merthyr Tydfil, see Jones, Explorations and Explanations, pp. 83-214.

56 “A Briton", letter, Welshman, 27 Nov. 1868.

${ }^{57}$ Carnarvon and Denbigh Herald, 28 Nov. 1868, declaration of poll for Carnarvonshire; ibid., 30 Dec. 1868, Conservative banquet at Carnarvon, speech of R. G. Duff, Vaenol; ibid., 21 Nov. 1868, similar comments of Sir Watkin Williams Wynn at the declaration of the poll for the borough seat. 
be made to establish how the community responded to the alleged exercise of "clerical influence".

The organizational role of the Catholic clergy in rural areas of Ireland and the Continent was matched by that of the nonconformist ministers in Wales. Their influence was notable at all stages of the election process. In the period before the election, they assisted with the preparation of the electoral registers and, as the election itself drew near, were involved in the selection and endorsement of Liberal candidates. ${ }^{58}$ Throughout the campaign, ministers allowed their chapels to be used as centres for local Liberal party organization: political meetings were often held in chapels, and some had the Liberal candidates' posters permanently on display. ${ }^{59}$ The preachers themselves, meanwhile, proved as "active and valuable" canvassers as ever: their appeals to the people were considered particularly "strong and effective", since "the promise of a man made to a preacher would not be broken". ${ }^{60}$ At public meetings, ministers played a leading role. In the more remote villages they often provided both the chairman and the larger proportion of the speakers. ${ }^{61}$ Even in the towns, where the scale of proceedings was grander, they were prominent: at Thomas Love Jones-Parry's meeting in Carnarvon, for example, seven of the nine speeches were delivered by nonconformist ministers. ${ }^{62}$ At the same time, the denominational meetings continued to endorse the proceedings of Liberal

${ }^{58}$ Anglesey: ibid., 4 July 1868; Merioneth: ibid., 11 July 1868 (Corris Liberal Society). See also editorial, Carmarthen $7 l, 28$ Aug. 1868 (meeting of fifty ministers in the town); Osvestry Advertiser, 2 Sept. 1868; Carnarvon and Denbigh Herald, 26 Sept. 1868 (Calvinistic Methodist General Assembly of North Wales). For similar involvement by priests in Ireland, see Whyte, Independent Irish Party, p. 79.

${ }^{59}$ Nonconformists did not regard their buildings as "sacred", and thus they were used for a wide variety of secular purposes: Carmarthen $7 l, 13$ Nov. 1868; National Lib. of Wales, Tredegar Park MSS., 71/707, canvassing diary of Octavius Morgan, M.P., entry for 23 Sept. 1868, on the area in the hills above Blaenavon.

60 "One of the Newly Enfranchised", letter, Welshman, 21 May 1869; B. T. Williams, letter, ibid., 28 May 1869. The activities of the preachers as canvassers are attested in the legal bills of solicitors employed by the Liberal candidates during the campaign: National Lib. of Wales, D. T. M. Jones MSS., 6136, bill of Benjamin Evans to E. J. Sartoris, 1868, entry for 12 Sept.; Carmarthen Record Office (hereafter Carmarthen R.O.), Glasbrook MSS., 23, uncatalogued bills containing many other examples.

${ }^{61}$ Newport Gazette, 19 Sept. 1868.

${ }^{62}$ Carnarvon and Denbigh Herald, 21 Nov. 1868. In the more cosmopolitan and wealthy southern industrial belt, however, preachers played a far less prominent role, the organization falling instead on the shoulders of the well-developed middle-class of these towns. The same was true in Ireland: Hoppen, Elections, Politics and Society in Ireland, p. 233. 
candidates and supporters, and thus appropriated to themselves the right of commenting authoritatively on public affairs and shaping popular reaction to events. ${ }^{63}$

Conservatives alleged, however, that the ministers' involvement went further than mere support for, and organization of, the Liberal campaign. They claimed that the preachers were attempting to force their congregations to vote for Liberal candidates, and threatening them with anything from excommunication to eternal damnation if they refused to comply. As the agent of one of the leading estates in west Wales remarked after the election, whatever pressure had been put upon tenants by their landlords, it was "certainly nothing to be compared with the systematic intimidation of the Dissenting Preachers". ${ }^{64}$

During the campaign, several cases were brought to light which were held to illustrate this aspect of the nonconformist ministers' involvement. Conservative propagandists, for example, seized upon a circular issued by the Liverpool-based Welsh Reform Association, a body dominated by the Independents, which had appeared in the Independent periodical $Y$ Dydd. The following translation was reprinted in the Carmarthen fournal and several other Conservative newspapers in Wales: ${ }^{65}$

CAUTION: Be it known to the electors of Anglesea, Carnarvon, Denbigh, Merioneth, Cardigan, and all the plains and hills of Wales, that a "Book of Remembrance" is being prepared to record the name of every Dissenter who shall vote for a Tory; and that persons will be appointed in every neighbourhood to escort every one of such over the stiles and through the gates from chapel to church, with the following recommendation: "As

\footnotetext{
${ }^{63}$ National Lib. of Wales, Calvinistic Methodist Archive, C 15/1, unpaginated notebook of William Roberts, draper, "Tachwedd $2+3$ ", 1868. The Calvinistic Methodists of Arfon resolved to send a message of thanks to Lord Newborough, Captain Wynne-Finch and the Revd J. W. Ellis after they had announced that their tenants would be free to vote as they pleased: J. E., letter, Carnarvon and Denbigh Herald, 7 Nov. 1868. For the Independents of Anglesey, see ibid., 25 July, 17 Oct. 1868. Most of Wynne-Finch's tenants duly split between the two Liberal candidates in Denbighshire: National Lib. of Wales, Voelas MSS., letter-book 4, fo. 29, A. H. Trewethy to C. Wynne-Finch, 28 Nov. 1868.

${ }^{64}$ Carmarthen R.O., Cawdor MSS., box 141, T. Mousley to Lord Cawdor, 21 May 1869.

${ }^{65}$ Editorial, Carmathen $f l, 30$ Oct. 1868; Monmouthshire Merlin, 31 Oct. 1868; Monmouthshire Beacon, 31 Oct. 1868; Pembrokeshire Herald, 13 Nov. 1868. It is unclear what relationship this document bears to motions presented at the meeting of the Welsh Independent ministers and church officers in early October 1868, proposing that watchers should indeed be appointed and the names of those who voted for Conservative candidates published in a "Black List".
} 
you consider that the Established Church is the best for others, it should suffice for you".66

Here, the threat of excommunication for those who did not vote for Liberal candidates was made quite plain. Although Conservatives regarded this warning as triumphant proof of ministerial coercion, the Liberal press defended it stoutly. The editor of the Oswestry Advertiser, for example, supported the principle of such "chastisement": "Every Dissenter is a Liberal from necessity on the subject of the general election, viz. the Irish Church. If he votes for a Tory . . . he is the murderer of his principles, and he should be treated as a moral murderer". ${ }^{67}$

A very similar exchange took place after the election in Monmouthshire. At their monthly meeting, the Association of Welsh Baptists in that county issued a resolution condemning "to the utmost extent . . . the unworthy conduct of the Baptists (?) who gave their votes to the Tories at the last election". "The fundamental principles of the Baptist Connection", they argued, "bind every member to defend religious liberty, and to oppose every sort of connection in Church and State, so that no Baptist has any right whatever to choose between a Liberal and a Tory". It concluded that those who had voted for the Conservatives had displayed either "lamentable ignorance" of their principles as Baptists or "wicked unfaithfulness". ${ }^{68}$ This resolution was condemned even by Liberal newspapers such as the Star of Gwent, but the Baptists of Monmouthshire remained undaunted. The Revd John Jones, who had originally proposed the motion, wrote to the editor of the newspaper defending his action. The Baptists had very particular views on baptism and communion, he wrote:

The idea that the connection should pretend to tolerate another to worship God according to personal convictions, is, in our opinion, really outrageous . . . and amounts to something not far short of blasphemy . . . Is it right that we should censure and expel delinquents in respect of baptism and communion, and unblushingly wink at the individuals who have done all they could to promote the interest of the Established Church in Ireland and elsewhere . . .? Let conscience supply the answer. ${ }^{69}$

${ }^{66}$ This is presumably the advertisement that the Revd Michael D. Jones denied having seen: Report from the Select Committee on Parliamentary and Municipal Elections, qq. $6747-8$.

${ }^{67}$ Editorial, Oswestry Advertiser, 4 Nov. 1868.

${ }^{68}$ Cited in editorial, Star of Gwent, 13 Feb. 1869.

${ }^{69}$ Revd J. Jones, letter, ibid., 20 Feb. 1869. Jones was perhaps better known by his bardic name "Mathetes". See also "Idwal", letter, Monmouthshire Merlin, 6 Mar. 1869; “John Ap Kent”, letter, ibid., 13 Mar. 1869. 
Both examples highlighted the same principle: nonconformists were to vote for Liberal candidates because that party supported the disestablishment of the Church of Ireland. Those who were not prepared to vote for this policy, which enshrined a central tenet of their dissent, had no place within their denominations. ${ }^{70}$ In effect, the ministers sought not only to present a vote for a Liberal candidate as a vote for conscience, but a vote against a Liberal as a vote against conscience, laying the guilty party open to all the sanctions, communal and (potentially) spiritual, that went with such a judgement. ${ }^{71}$ As one correspondent of the Welshman wrote: "the Welsh preachers . . . venture to prescribe rules of faith and conscience which their English co-religionists would never dare to do". ${ }^{72}$

The appearance of such debates in the newspapers was one thing; what concerned Conservatives, however, was the extent to which these rigorous principles were enforced at the local level by the nonconformist ministers. A large part of the Liberal party's political message was, indeed, being delivered at the grass roots level through an essentially religious medium. Many Liberal meetings, especially in more remote country areas where alternative public buildings were scarce, were held in chapels and addressed by the local minister along with the candidate. Conservatives feared that the unsophisticated rural electorate might be led by their surroundings to believe that the political messages they heard in the chapels were, in some way, divinely sanctioned. Even when meetings were not held in chapels, the language and rhetorical tactics of the ministers bore a striking resemblance to those used on more overtly religious occasions: the appeal to "conscience" was made through language rich in religious imagery.

Politics was represented as a battle between good and evil. At a large Liberal demonstration in Newport, for example, the Revd

\footnotetext{
${ }^{70}$ For a series of similar resolutions passed by the Calvinistic Methodist Association of North Wales, see Carnarvon and Denbigh Herald, 26 Sept. 1868.

${ }^{71}$ This was not unique to the 1868 election. One of the circulars issued by ministers in Carmarthenshire in 1837 told tenants who intended to vote against the Liberal candidate: "you pray to God, and when He answers your prayers, you hold up your hands against Him": Cragoe, "Carmarthen County Politics", pp. 75-6.

72 "C.", letter, Welshman, 25 Dec. 1868 . This certainly seems to be true on a general reading of English debates about disestablishment. Even the Revd R. W. Dale, chairman of the Congregational Union, presented it less as a matter of "conscience" than of "Justice to Ireland", which was the standard Liberal line in England: Warwickshire Chronicle, 24 Nov. 1868.
} 
H. Oliver remarked that Conservatism was essentially pagan, whilst Liberalism, with its belief in progress, was essentially Christian. ${ }^{73}$ In Merioneth, the Revd E. Morgan told an audience gathered in the British schoolroom at Dyffryn Ardudwy that "the principles of Toryism and Liberalism were as different as light from darkness". ${ }^{74}$ A preacher in Carmarthenshire, meanwhile, apparently called upon God to protect his flock from the Conservative canvassers, whom he described as "the Servants of the Devil". ${ }^{75}$ In more local matters, speakers had frequent resort to biblical imagery in order to convey the moral content of their message. Thus the Tories' undisturbed seventy-year tenure of the Carnarvonshire county seat was always presented as a "Babylonian captivity" during which the Liberals had been obliged to hang up their harps on the weeping willows; ${ }^{76}$ Carnarvonshire Toryism itself was compared by the Revd R. W. Griffith of Bethel to the tree seen by Nebuchadnezzar in his dream, a tree that must be hewn down and uprooted; ${ }^{77}$ while the Revd Mr Richards told an audience in the Calvinistic Methodist chapel at Llanaelhaearn that "Toryism was raising a great idol now at Penrhyn Castle [the home of the Conservative candidate]", and demanding that all bow down before it, a demand they must resist. ${ }^{78}$ The Revd $R$. Pritchard, meanwhile, averred that Gladstone was another Moses, sent to release the working classes of Denbigh from bondage. ${ }^{79}$

On occasion, preachers used biblical examples to teach their audiences quite overtly from the platform. At a meeting in Carnarvon, the Independent minister, the Revd E. Evans, expressed his disappointment upon discovering that some local quarrymen intended to vote for the Conservative candidate supported by their employer on the grounds that the employer had been kind to them. Kindness and the payment of good wages should not be the basis of political decision-making, he said:

${ }^{73}$ Newport Gazette, 18 July 1868.

${ }^{74}$ Carnarvon and Denbigh Herald, 17 Oct. 1868.

75 "Truth and Justice", letter, Welshman, 18 Dec. 1868.

${ }^{76}$ See, for example, Carnarvon and Denbigh Herald, 10 Oct. 1868, T. L. JonesParry at Beddgelert. The allusion is to Ps. 137:1-2.

${ }_{77}$ Ibid., 17 Oct. 1868, T. L. Jones-Parry at Llanrug. Cf. Dan. 4:10-14.

${ }^{78}$ Ibid., 14 Nov. 1868.

${ }^{79}$ Ibid., 7 Nov, 1868, meeting for Watkin Williams at Henllan Calvinistic Methodist chapel, also meeting at Aberdaron, speech of the Revd G. Hughes, Edeyrn. 
I would ask you, do you recollect the first temptation? - it was this "Command these stones be made bread". He wanted bread at the time, he was hungry. He knew that he possessed the power to transform the stones into bread, but he refused, and in that one lesson he taught the ages that it was not right for any man to earn his bread in a wrong way. When a man gives his vote merely because the gentry buy at his shopwhat is that? "Commanding the stones to be bread." When a man allows himself to be screwed into silence merely because he gets an extension of lease for his house, what is it? "Commanding the stones to be bread" (hear, hear and cheers). ${ }^{80}$

In this example, the extent to which the election had been reduced to a matter of simple "right" behaviour and "wrong" behaviour, an issue entirely within the purview of the congregation's normal relationship with their minister, is transparently clear.

The appeal to conscience was not in itself "coercion". What made it illegitimate were the threats that accompanied it, and these can be divided into two varieties. Throughout the campaign, some ministers emphasized the burden of disgrace that those among the nonconformists would have to bear in the eyes of their local communities if they failed to vote for.Liberal candidates; others, more bluntly, calculated the price of a miscast vote in terms of eternal punishment. A striking example of the first was given by the Revd Robert Parry during a meeting in the Calvinistic Methodist chapel at Penmachno, Carnarvonshire. He warned the voters to behave like men, lest their wives and children should later suffer the scorn of their neighbours "because their husbands and fathers were not true men", and then related the story of the man who betrayed his country to Philip of Macedon. The man subsequently complained to Philip that his new countrymen called him "betrayer":

"Well", said Philip, "the people of Macedon call every object by its proper name, and the only name they have for black is the word black": the people of Carnarvonshire, Liberals and Tories, will have no other name for you, if you become unfaithful to your principles, than "the betrayer" (great applause). ${ }^{81}$

On other occasions, the message was couched in more homely terms, as when the Revd D. Roberts asked another meeting in Carnarvonshire how, if the Tories won, any nonconformist who had voted with them could dare to raise his head again in society, while if the Liberals won, such a man could ever again attend a

${ }^{80}$ Ibid., 17 Oct. 1868, meeting for T. L. Jones-Parry at Carnarvon. Cf. Matt. 4:3.

${ }^{81}$ Ibid., 24 Oct. 1868. 
market or a fair and look his fellows in the eye ${ }^{82}$ Both these examples, it should be noted, involved nonconformist ministers addressing people in their own chapels, and inviting members to consider the social consequences of violating their nonconformist principles. A similar line was taken by a preacher in Brecon, who apparently told his congregation that any among them who voted for the Conservatives would have their names posted on the walls of the chapel. Giving evidence to the Select Committee on Parliamentary and Municipal Elections, Arthur Cheese, a Brecon solicitor, maintained that such posting implied that the named person would be brought before the managing body of the chapel and expelled: it would be looked upon as a "disgrace". ${ }^{83}$

After the election, the Conservatives produced many alleged examples of the second species of coercion identified above, the so-called "religious screw". A correspondent of the Welshman described a series of incidents which apparently occurred in Cardiganshire. Typical was the action of a preacher during a political meeting at Penuwan chapel. He called upon a farmer to pledge his vote for the Liberal candidate, and when the man refused the preacher called him a "slave" subject to the landlord "screw". The farmer denied this, and the preacher then broke into extempore prayer before the meeting, imploring him who had opened Lydia's eyes to do the same for this "despicable sinner". ${ }^{84}$ Another correspondent gave further examples from the same county. Two men who wanted to vote for the Conservative candidate, Mr Vaughan, were apparently told by the preacher of Penmorfa chapel that it was a "matter of the soul", and that "neither of them had a chance of being saved in the day of the Lord, if they voted against $\mathrm{Mr}$ Richards [the Liberal candidate]". At Llangranog, meanwhile, the preacher was reported to have said that he knew all the dissenters in the lower half of the county, and that if he saw any of them voting for Vaughan, he would "expose them without mercy". 85 Others produced similar stories in which excommunication was threatened if members of the congregation did not vote as

\footnotetext{
82 Ibid., 31 Oct. 1868, meeting for T. L. Jones-Parry at Dolbenmaen Baptist chapel.

${ }^{83}$ Report from the Select Committee on Parliamentary and Municipal Elections, qq. 5068-70.

84 "Cymro", letter, Welshman, 2 Sept. 1869. Cf. Acts 16:14-15.

85 "Truth and Justice", letter, ibid., 18 Dec. 1868.
} 
directed. ${ }^{86}$ In all these cases, as one "Old Tory" put it, the ministers made "a handle of conscience". ${ }^{87}$

Nonconformists denied the charges brought by the Conservatives. The quarterly meeting of Welsh Baptists at Bangor and the Calvinistic Methodists in their monthly meeting at Arfon, for example, both issued addresses denying that the ministers had used any improper influence during the election. ${ }^{88}$ Liberal politicians also leapt to the chapels' defence, taking up two positions in the process. The main body of Liberal opinion sought simply to deny that any coercion had or even could have taken place. There had been no need for the ministers to use force, said Thomas Harries, a Cardiganshire landowner, because they and their congregations were on the same side. ${ }^{89}$ The Revd $\mathrm{Mr}$ Evans of Llansantffraed made the same point more wittily: "a vessel which sailed before the wind", he said, "did not require any screw to drive it (hear, hear and cheers)". ${ }^{90}$

Alongside these defences of the nonconformist ministers went a second, more interesting, strand of argument, which while admitting their involvement, carefully qualified it as having been confined to the development of conscientious voting among their congregations. "Suetonius", a correspondent of the Welshman, said he had "heard them [the ministers] speak of conscience, of principle, of consistency, of fidelity to one's professions", but never to have uttered a word of threat to any member of a congregation. ${ }^{91}$ Others, however, were prepared to go a little further down the same road. The editor of the most influential English-language newspaper in North Wales, the Carnarvon and Denbigh Herald, devoted an article to the subject. The Liberals of Carnarvonshire, he noted, had been accused of using the

\footnotetext{
${ }^{86}$ Report from the Select Committee on Parliamentary and Municipal Elections, q. 5066; editorial, Pembrokeshire Herald, 28 Aug. 1868; Carnarvon and Denbigh Herald, 17, 24 Oct. 1868, speeches by $\mathrm{Mr}$ Copner $\mathrm{W}$ ynne Edwards at meetings for the Conservative candidate, T. Mainwaring.

87 "'Old Tory", letter, Welshman, 4 June 1869.

${ }^{88}$ Carnarvon and Denbigh Herald, 12 Dec. 1868, 2 Jan. 1869.

${ }^{89}$ Report from the Select Committee on Parliamentary and Municipal Elections, qq. 6284-90.

${ }^{90}$ Carnarvon and Denbigh Herald, 9 Jan. 1869. For similar views, see B. T. Williams, letter, Welshman, 28 May 1869; Report from the Select Committee on Parliamentary and Municipal Elections, qq. 6285-7, 6596-9; John Jones of Llandilo, letter, Welshman, 4 June 1869; ibid., 26 Feb. 1869, report of Liberal banquet in London, speech of E. M. Richards, M.P. for Cardiganshire; “An Old Subscriber", letter, Carnarvon and Denbigh Herald, 12 Dec. 1868; "Towy" and Mr Tymins, letters, ibid., 19 Dec. 1868.

91 'Suetonius", letter, Welshman, 11 Dec. 1868.
} 
"Screw Religious". "We are disposed", he said, "to acknowledge that we have used this mode of persuasion: to avow, indeed, that it is a legitimate and a most righteous one". He justified this as follows:

If a man holds conscientious opinions, and yet at the bidding of another human being, from motives of personal interest, or selfish indolence, deliberately acts in direct antagonism to his private judgement, he seems to us to deserve disgrace and contempt in this world, and the punishment of a liar and a coward in the next. If telling a friend that he would merit such disgrace and punishment by such neglect of his duty is the "screw religious" we cannot but approve of such pressure, and we would venture to say that a minister of religion, of whatever Church, fails in his duty if he does not, among other precepts, inculcate fearlessness and truthfulness in the declaration of political opinions at all fit times and occasions. ${ }^{92}$

The editor of the Cambria Daily Leader agreed, declaring that the ministers "have no weapons in their quiver which they ought not to use". 93

This argument accorded the preacher the kind of moral influence that it was suggested earlier he did in fact possess, and also indicated that it was a power he was expected by the community to exercise. This was made very clear in the defence which the deacons of a chapel in Llanddewi-Brefi, Cardiganshire, offered for the conduct of their minister, the Revd Abraham Oliver, during the election. He had been accused of encouraging a mob on election night to burn an effigy of the Conservative candidate, and of having then flung a copy of the bible into the flames after it. It later transpired that he had been five miles away at the time, and that the whole affair had been got up by some children. ${ }^{94}$ Nevertheless, the deacons' letter was of considerable interest as an indicator of grass-roots opinion about the relationship between pastor and congregation on political matters. It confirmed the influence of the preacher over the communal life of the chapel: "We look to him", they wrote, "for counsel in all religious and civil matters, and as a living pattern to us in all his acts and doings, to guide us in our respective paths through this world". They admitted his right to take a strong course in politics. Several

\footnotetext{
${ }^{92}$ Editorial, Carnarvon and Denbigh Herald, 21 Nov. 1868. The involvement of the Catholic clergy in Ireland was justified on similar grounds: Hoppen, Elections, Politics and Society in Ireland, pp. 191-3; O'Shea, Priest, Politics and Society in Post-Famine Ireland, p. 45.

${ }^{93}$ Editorial, Cambria Daily Leader, 9 July 1869.

${ }^{94}$ Inglis Jones, letter, Welshman, 16 July 1869; "A Conservative", letter, ibid., 2 Sept. 1869; Revd Abraham Oliver, letters, Oswestry Advertiser, 18, 25 Aug. 1868.
} 
of their number, they said, had been obliged to vote Conservative at the election: "Seeing the predicament we were in, as well as many others in his congregation, Mr. Oliver acted kindly and charitably towards us, condoling with us, when, as a matter of course, he had a right as our pastor to interfere and remonstrate with us for violating our professed principles". ${ }^{95}$ When viewed in this light, the charges made by the Conservatives seem credible enough, because they are explicable within the framework of expectation inhabited by the nonconformist ministers and their congregations. The threats of hell-fire for wrong votes were not, on this showing, the cynical manipulation of ignorant voters by political partisans, but sincere expressions of opinion as to the likely consequences of ignoring one's professions of faith. That it was considered by the community at large to be the preacher's job to make these matters clear to his congregation is also plain.

The extent to which politics came within the purview of the community's shared moral values can also be seen in the surviving evidence of division within individual chapels. As he was on the point of administering the sacrament on the Sunday prior to the election, one dissenting minister in Cardiganshire apparently put it to a vote of the congregation whether the deacons should be allowed to partake, as they were going to vote for the Tory candidate the following week. The congregation followed their minister and voted against the deacons. ${ }^{96}$ On the Sunday following the election, some members of the Independent chapel at Llanfair Clydogau in the same county refused to take communion with those who had voted for the Conservatives. They believed them "to be great sinners, hypocrites and traitors to the tenets and faith of their church", and demanded their excommunication. ${ }^{97}$ Elsewhere, apparently, individuals were indeed excommunicated. A Mr Davies of Wenallt was ejected from the Sunday school at his local chapel for having voted Conservative. ${ }^{98} \mathrm{~A}$ respectable farmer from Llanarth, having decided voluntarily that his presence might not be welcome in the chapel after he had voted for the Conservative candidate, was surprised to receive a letter from

\footnotetext{
${ }^{95}$ David Lewis, David Evans, David Williams et al., letter, Oswestry Advertiser, 15 Sept. 1869.

96 "Anti-Humbug", letter, Carmarthen $7 l, 11$ Dec. 1868.

97 "R.", letter, Welshman, 11 Dec. 1868.

98 "Cymro", letter, ibid., 2 Sept. 1869.
} 
his chapel a few weeks later informing him that he was welcome to return, as his "offence was forgiven". 99

Excommunication was, of course, the ultimate sanction that the community could impose upon an individual. Exclusion for political reasons apparently took the same form as exclusion for "very flagrant immorality": expulsion for a time, and readmission when the guilty person was suitably penitent. The preacher's action at the Penuwan chapel, when he remonstrated with the farmer in front of the meeting, was, similarly, what one correspondent of the Welshman described as "a reproof administered in the face of the congregation ... intended to put the individual to shame before the little world he lives in". ${ }^{100}$ In all these cases the acceptance by the community of his authority was the essential precondition of the minister's "coercive" activities. As such they are perhaps best considered a form of chapel-community morality, and it is upon the links between the older means by which the community at large enforced its moral code and the chapel discipline of 1868 that attention must now be focused.

\section{III}

The tradition of secular community discipline symbolized by the skimmington and "rough music" had remained very strong in parts of rural Wales into the early nineteenth century. The west Wales version was known as the ceffyl pren (wooden horse). Those suspected of moral decadence might receive threatening letters, beatings, harassment and, of course, the indignity of the skimmington itself. ${ }^{101}$ In the early 1840 s this process was subsumed within the broad social ferment which accompanied the breaking of toll-gates during the Rebecca Riots. The farmers (or their sons) played an important role in the organization of this shadowy guerrilla movement, as indeed they had long done in the more formal surroundings of the vestry. ${ }^{102}$ The willing and unwilling alike were forced by "Rebecca" to heed her call to arms on

99 "Index", letter to the Standard, cited in Carmarthen fl, 22 Oct. 1869.

100 "Truth and Justice", letter, Welshman, 18 Dec. 1868.

${ }^{101}$ Jones, Rebecca's Children, p. 160.

102 Ibid., pp. 92-3, 212-13, 245-6. The presence of the larger farmers in the "crowd" might indicate the general poverty of the Welsh countryside, which may in turn have been an important factor in keeping alive this form of collective morality: Reports of the Commissioners of Inquiry into the State of Education in Wales, i, p. 244 (St Clears). 
occasions such as the attack on the Carmarthen workhouse. ${ }^{103}$ In other areas, such as the iron districts of south-east Wales, other groups like the "Scotch Cattle" performed a similar function. ${ }^{104}$ Examples of something like the old ceffyl pren can even be found later in the century. In Carnarvon in 1868, a woman who had married a much older man as his second wife was paraded around the streets tied to a ladder. ${ }^{105} \mathrm{E}$. P. Thompson unearthed a similar example from a still later date: in 1898, a report from Llanbister in Radnorshire described the action of a "Rebecca" gang on the houses of a man and a woman who had made some "breach of the laws of morality". ${ }^{106}$

If, by 1868 , a large section of community morality on issues such as drunkenness and adultery had been subsumed within the chapel, and the older shaming rituals such as the ceffyl pren comprehended within the chapel's own disciplinary procedures, there yet remained echoes of an earlier order underpinning the new. Running alongside the chapel's authority was another, semisecular current of discipline, using older forms such as arson and threatening letters, but relating such actions to the authority of the chapel. In this section, the rather fragmentary evidence left by this hybrid will be examined.

At times, ministers themselves were to be found hinting at violent retribution for those who failed to toe the communal line. The Revd W. Jones of Porthmadog, for example, having told an audience in the town that they would be "Iscariots" if they did not vote for the Liberal candidate, said that it was a problem to know what to do with those who still refused. He continued: "One of the boys there had the night before proposed to tar them, but he was afraid that would be too long a process (great laughter); if they were in America they very likely would be tarred (laughter)". ${ }^{107}$ Said in jest or otherwise, these were strong words, especially from a preacher in his home town. In another incident, a young preacher told an audience that he considered it

${ }^{103}$ D. Williams, The Rebecca Riots (Cardiff, 1955), pp. 205-6, 236-41.

${ }^{104}$ D. J. V. Jones, Crime, Protest, Community and Police in Nineteenth-Century Britain (London, 1982), p. 101.

${ }^{105}$ Norfolk Chron., 1 Aug. 1868, special suppl. The ladder was apparently freshly tarred. The group comprised men and women, and those later caught were fined one sovereign each.

106 Thompson, "Rough Music", p. 523.

${ }^{107}$ Carnarvon and Denbigh Herald, 24 Oct. 1868. 
a "right thing to make a football of the Conservative candidate's head". 108

Most examples, however, did not involve nonconformist ministers directly. In some areas farmers were said to have received nocturnal visits or anonymous letters threatening arson or beatings if they failed to vote for Liberal candidates. One magistrate in Merioneth was so alarmed by reports of such threats in his neighbourhood that he wrote to the home secretary requesting the presence of a detachment of troops on polling-day. Perhaps thankfully for all concerned, the Liberal candidate, David Williams of Castelldeudraeth, was eventually returned unopposed. ${ }^{109}$ A tenant of the Alltyrodin estate in Carmarthenshire, Evan Jones, received a threatening letter wrapped around two lucifer matches. It read:

If you do not vote against your landlord, and in the same way as your brother, John y Logyn - BEWARE - Perhaps you may see the Rev. Thomas Thomas as kind to you as the heir to Alltyrodin. Tell the same thing to the other Alltyrodin tenants who have not turned. ${ }^{110}$

The heir, it may be assumed, had been threatening tenants with eviction should they vote Liberal: the minister's "kindness" to those who voted with the Conservatives would presumably have taken a like form, probably exclusion from the chapel. It is interesting to note that the threat of arson indicated by the matches was made in association with the morality enshrined in the local chapel. A similar link emerged during an incident in Cardiganshire, where the farmer of Bryncethin received a mysterious caller at midnight on 25 November 1868. The unexpected visitor told him that:

it was a very important crisis, a great struggle between Christ and the Devil; and after referring it to his conscience many times, said that this was his ultimatum. If he was not going to vote for Mr Richards [the Liberal candidate], the man whom the Lord had sent them, he would be lamenting, when too late, for not "listening to the voice of his teachers".

In this case, the threat was delivered in a very traditional manner,

\footnotetext{
108 "Cymro", letter, ibid., 12 Dec. 1868; Report from the Select Committee on Parliamentary and Municipal Elections, qq. 6743-6.

${ }^{109}$ Henry Thomas Richardson, J.P., Aberhirnant, Merioneth, letter, Oswestry Advertiser, 25 Nov. 1868. It has not been possible to locate this letter in the Home Office files in the Public Record Office, London.

${ }^{110}$ Welshman, 20 Nov. 1868.

111 "Cymro", letter, ibid., 2 Sep. 1869. There is possibly an allusion here to Prov. 5:10-13: "Lest ... thou mourn at the last, when thy flesh and thy body are consumed, and say,... [I] have not obeyed the voice of my teachers".
} 
anonymously and at night, but the authority which was invoked to legitimate it was that of the chapel.

A second wave of this semi-secular community discipline became evident after the election, in connection with the eviction of some tenants from their farms for having voted Liberal and the establishment of a fund from which to compensate them. For example, the father-in-law of the incoming tenant of the farm of Pobty on Colonel A. S. Davies's estate, the scene of an alleged "political" eviction, received a letter saying that it would be burnt down. Enclosed was an article from the radical newspaper $Y$ Dydd, edited by the Revd Samuel Roberts, reading: "I am sorry to see that some persons have had the presumption to take farms of those who have had notice to quit. I would not give much for their property next Christmas Day, and I should not like to insure their lives either". 112 The covering letter assured the recipient that "Old Becca" was not dead. ${ }^{113}$ The incoming tenant of a cottage owned by Captain Jordan of Pigeonsford received a brace of threatening letters, written in Welsh. The first letter warned him that the farmers in the area were "very turbulent" about the eviction from that cottage of the previous tenant, William Nicholas, and were "sure to put everything you have on fire". The second, a few days later, brought the religious factor to the forefront:

$\mathrm{Sir}$, It is known to you that it was because Wm. Nicholas was not of the same views as his master, he had to go away, and because you are of the same views as he [the master], you had the place of your neighbour. We have in the Bible: "Thou shalt not covet thy neighbour's house, \&c." and you have broken that commandment; and this is what $I$ have to inform you, if you shall not have departed thence before the lapse of a few days, you shall see your mistake.

To complete the link between the old community morality and the new, the letter was signed: "One who will have fair play. BECCA". ${ }^{114}$ The connection was again implicit in a letter received by Mr John Davies of Dyffryn, a tenant of Colonel A. S. Lewis, vowing that if he did not contribute substantially to the fund then being collected for the compensation of the evictees, "there will be something revengeful done before long to a cow or horse,

\footnotetext{
112 Western Mail, 11 Jan. 1870.

${ }^{113}$ Editorial, Carmarthen $7 l, 31$ Dec. 1869.

114 Welshman, 14 Jan. 1870; the allusion is to Exod. 19:17. Captain Jordan was a Conservative, but he denied that Nicholas was evicted for political reasons: Carmarthen $\mathfrak{f l}, 24$ Dec. 1869, 22 Jan. 1870.
} 
or a lead bullet for yourself". ${ }^{115}$ The collections for the fund, which was organized by the Independents in Liverpool, were made in every chapel in Wales on the first Sunday in 1870.

\section{IV}

In Victorian Wales, therefore, as in Victorian Ireland and in parts of continental Europe, the "priest in politics" was a familiar figure in the electoral landscape. It has been the argument of this article, however, that the accusations of "clerical influence" common to all countries are, in Wales at least, better understood as evidence of the continuation of a strong tradition of community morality in rural areas of the principality rather than as anything more sinister. ${ }^{116}$ As E. P. Thompson has written, although 1843 marked the cession by Rebecca of her temporal authority, "her spiritual dictatorship survived for much longer". ${ }^{117}$ It is suggested here that the place which gave her shelter in these later years was in fact the nonconformist chapel, and that in return she lent the men who presided over the chapels a portion of her former authority to wield in the community. ${ }^{118}$ That discipline, however, by its very nature was the expression of a moral code belonging to the whole community, and could only be exercised with the consent of that community, or at least of the majority.

At one level, the link between the chapel and the old-style communal discipline is surprising, since the advance of evangelical religion is frequently held up as the antithesis of the "old ways of playing", it having done its utmost to impose a new order on mid-Victorian Britain. ${ }^{119}$ So, indeed, it did, but it may be that

115 "Suetonius", letter, Cambria Daily Leader, 12 Jan. 1870; Welshman, 7 Jan. 1870; Western Mail, 19 Jan. 1870. The spate of arson threats in the Cardiganshire region was so serious at this time that a London insurance firm apparently refused to insure the property of Colonel Powell of Nanteos, who had been accused of several political evictions: "Cheshire", letter, Carnarvon and Denbigh Herald, 13 Nov. 1869.

${ }^{116}$ For conspiracy theories among the French left, see Cubitt, fesuit Myth, pp. 278-89.

117 Thompson, "Rough Music", p. 523.

${ }^{118}$ At Rebecca meetings, the preachers spoke out against violence to persons and property: Jones, Rebecca's Children, pp. 332-3. It is perhaps more significant that they were there at all; their presence is another indication of communal solidarity between congregations and preachers, and the involvement of the latter with all aspects of life.

${ }^{119}$ R. Holt, Sport and the British: A Modern History (Oxford, 1989), p. 41; Davies, Religion and Society in the Nineteenth Century, pp. 64-5; R. A. Jones, "Popular Culture, Police and the 'Disappearance' of the ceffyl pren in Cardigan, 1837-1850", Ceredigion, xi (1988-9), pp. 19-39. 
the break has been overstated, and that one of the reasons why nonconformity was so successful in the Welsh countryside was that it operated within an older vernacular culture with which people were already familiar. Perhaps the same is true for other religions in other areas. Nonconformity in the principality grew from below, in that social space created by the neglect and decay of the Anglican church. ${ }^{120}$ As such, it colonized a society which already had its own structure of authority and discipline. ${ }^{121}$ The Rebecca Riots demonstrated this mechanism at work just twentyfive years prior to the general election of 1868. That movement had been dominated by the farmers and the other groups of high status in the countryside: when the labourers began to agitate on their own behalf, the farmers quickly ended their own involvement. ${ }^{122}$ In large areas of rural Wales, where the economy remained undiversified, no new class rose to challenge the authority of the farmers and their allies. To the extent that these same groups came to provide the diaconate of the nonconformist chapels, and thus to give a lead to the disciplining of moral life in the community, it seems reasonable to argue that the chapels grew round the customary social usages, modifying and formalizing them, perhaps, but ultimately internalizing them, not sweeping them away. ${ }^{123}$

The role of the nonconformist minister was to give a focus to this community morality and to the discipline that went with it. ${ }^{124}$ When the subject under consideration was politics, the minister possessed a position of great power as the interpreter of the moral content of all issues which came before the congregation. To Conservatives, the threat posed by these men was perceived at an individual level, yet what underpinned the efficacy of the appeal to conscience was the acquiescence of the

${ }^{120}$ F. C. Mather, High Church Prophet: Bishop Samuel Horsley (1733-1806) (Oxford, 1992), pp. 163-77; H. T. Edwards, Church of the Cymry; Cragoe, "Tory and Anglican Gap in Welsh Historiographical Perceptions", pp. 279-86.

${ }^{121}$ Nonconformity did not "throw up" a new class of leaders: cf. Verdery, "Ethnicity and Local Systems", p. 206.

${ }^{122}$ D. Howell, "The Rebecca Riots", in T. Herbert and G. E. Jones (eds.), People and Protest: Wales, 1815-1880 (Cardiff, 1988), p. 119.

${ }^{123}$ Since the same groups dominated nonconformity in the English countryside the same link may apply there too: J. H. Porter, "The Development of Rural Society", in The Agrarian History of England and Wales, vi, 1750-1850, ed. G. E. Mingay (Cambridge, 1989), pp. 889-90.

${ }^{124}$ Report from the Select Committee on Parliamentary and Municipal Elections, q. 5119. 
community in the right of the chapel hierarchy to adjudicate the morality of any given issue and enforce conformity to their decision. It was the secular discipline thus enshrined in the chapels, rather than simply the religious feeling of the people, that made the chapels such an enduring focus for the mobilization of Liberal sentiment in the principality.

It may be that the involvement of the Catholic clergy in Irish politics worked within a similar context. The strong division in Irish society between farmers and labourers, the farming background of the priests, and the strength of the alliance between priests and farmers in the post-Famine period, suggest the same link between secular and spiritual authority which was visible in the Welsh countryside. ${ }^{125}$ The manner in which priests addressed their congregations from the altar on political matters at election time, meanwhile, added to the violence which so frequently attended the passage of elections in the countryside, ${ }^{126}$ suggests a similar collective dynamic for "clerical influence" in Ireland as in the principality. In Wales at least, as this article has demonstrated, notions of collective morality were of central importance in politics throughout the mid-Victorian period.

University of Hertfordshire

Matthew Cragoe

${ }^{125}$ O'Shea, Priest, Politics and Society in Post-Famine Ireland, pp. 232-3; Kerr, Peel, Priests and Catholics, p. 247.

${ }^{126}$ Hoppen, "Grammars of Electoral Violence in Nineteenth-Century England and Ireland", pp. 613-14. 